\title{
Papillary Adenoma
}

National Cancer Institute

\section{Source}

National Cancer Institute. Papillary Adenoma. NCI Thesaurus. Code C79951.

An adenoma characterized by the presence of papillary epithelial patterns. 